\title{
TETRACYCLIC TRITERPENOIDS FROM Euphorbia nicaeensis All.
}

Gordana B. Krstić ${ }^{1}$, Miroslav M. Novaković2 ${ }^{\star}$, Milka B. Jadranin², Vele V. Tešević ${ }^{1}$

1 University of Belgrade, Faculty of Chemistry, Belgrade, Serbia

2University of Belgrade, Institute of Chemistry, Technology and Metallurgy, National Institute, Belgrade, Serbia

In this study, three tetracyclic triterpenes: (3S,24S)-tirucall-7-ene-3,24,25-triol (1), (3S, 24R)-tirucall-7-ene-3,24,25-triol (2) and inoterpene C (3), were isolated from the milkweed Euphorbia nicaeensis All. using dry-column flash silica gel chromatography and semipreparative normal-phase HPLC. Their structures were determined on the basis of 1D and 2D NMR spectra and literature review. Although these three compounds have previously been isolated from other plant species, this is the first time that they have been isolated from $E$. nicaeensis.
(ORIGINAL SCIENTIFIC PAPER) UDC 582.682.1:547.596:543.544

Keywords: tetracyclic triterpenes, Eu phorbia nicaeensis, latex, dry-column flash chromatography, NP HPLC, NMR analysis

\section{Introduction}

The genus of Euphorbia is one of the largest and the most diverse genus with more than 2000 species. Plants of the genus of Euphorbia are a rich source of biologically active compounds. Among thousands of compounds derived from Euphorbia plants, diterpenes and triterpenes have been most commonly isolated ones. There are special plant cells in the stems of this plant - cells of laticifera, specialized in the production and accumulation of latex. Latex is often white or pale yellow in color and has a protective role - it repels herbivores and can have antifungal effects. The chemical composition of latex is highly variable, in fact, it represents a mixture of terpenoids. Triterpene alcohols do not show any significant biological activities, but they have proven to be very important chemotaxonomic markers. The most common triterpene alcohols of the Euphorbia plants latex are cycloartenol, lanosterol, butyrospermol and 24-methylene-cycloartanol [1]. In the previous investigations of latex of Euphorbia nicaeensis fifteen jatrophanes were isolated and chemically characterized, seven of which were new compounds [2].

\section{Experimental}

General experimental procedures

LC-DAD: Agilent Technologies 1260 Series liquid chromatograph equipped with diode-array detector $(\lambda=210 \mathrm{~nm})$ and autosampler; Program 1 (NP-HPLC), LC conditions: Injection volume $1000 \mu \mathrm{L}$ (c $10 \mathrm{mg} / \mathrm{mL}$, acetone), Zorbax RX-Sil (250 $\times 9.4 \mathrm{~mm} ; 5 \mu \mathrm{m}$ ), column temp. $24^{\circ} \mathrm{C}$, mobile phase $3.00 \mathrm{~mL} /$ min: $A$ (acetone) and $B$ (petroleum ether), isocratic mode of elution 18\% A/82\% B. Program 2 (NP-HPLC), LC conditions: Injection volume $1000 \mu \mathrm{L}$ (c $10 \mathrm{mg} / \mathrm{mL}$, acetone), Zorbax RX-Sil $(250 \times 9.4 \mathrm{~mm} ; 5 \mu \mathrm{m})$, column temp. $24^{\circ} \mathrm{C}$, mobile phase $3.00 \mathrm{~mL} / \mathrm{min}$ : A (acetone) and $\mathrm{B}$ (petroleum ether), isocratic mode of elution with $10 \% \mathrm{~A} / 90 \% \mathrm{~B}$. HRESIMS data were obtained on an Agilent 6210 time-of-flight LC/ MS system equipped with an ESI interface (ESITOFMS). The solvent was methanol, and the mobile phase was $0.2 \% \mathrm{HCOOH} / \mathrm{CH}_{3} \mathrm{CN}, 1: 1,0.2 \mathrm{~mL} / \mathrm{min}$. The ESI was operated in a positive mode and nitrogen was used as the drying gas (12 L/min) and nebulizing gas at $350{ }^{\circ} \mathrm{C}(45$ psi). The OCT RF voltage was set to $250 \mathrm{~V}$, and the capillary voltage was set to $4.0 \mathrm{kV}$. The voltages applied to the fragmentor and skimmer were 140 and $60 \mathrm{~V}$, respectively. The scanning was performed from $\mathrm{m} / \mathrm{z} 100$ to 1500 .

Dry-column flash chromatography (DCFC) and column chromatography (CC) were performed on silica gel (ICN Silica $12 \times 2660 \AA$ and $70 \times 230$ mesh, ASTM, Merck, respectively). Silica gel 60 F254 precoated aluminum sheets $(0.25 \mathrm{~mm}$, Merck) for TLC control were used.

Optical rotations were determined on an Autopol IV (Rudolph Research Analytical) polarimeter equipped with a sodium lamp (589 $\mathrm{nm}$ ) and $10 \mathrm{~cm}$ microcell. ${ }^{1} \mathrm{H}$ and ${ }^{13} \mathrm{C}$ NMR data were measured on Bruker Avance III 500 NMR spectrometer $\left(500 \mathrm{MHz}\right.$ for ${ }^{1} \mathrm{H}$ and $125 \mathrm{MHz}$ for ${ }^{13} \mathrm{C}$ NMR, in $\mathrm{CDCl}_{3}$ with TMS).

\section{Plant material}

The latex and the root of $E$. nicaeensis were collected from wild stock at Deliblato sands (Serbia) in June 2014 (latex) and in June 2018 (root) at latitude 44,93,008 $\mathrm{N}$ and longitude $21,17,769^{\circ} \mathrm{E}$. The plant was identified by Prof. Petar Marin, Institut of Botany, Faculty of Biology, University of Belgrade. A vaucher specimen (No 16855) was deposited at the Herbarium of Botanical Garden "Jevremovac" University of Belgrade, Belgrade (Serbia).

\section{Extraction and isolation}

The latex $(51.2 \mathrm{~g})$ of $E$. nicaeensis was lyophilized at $-70{ }^{\circ} \mathrm{C}$ to obtain dry material $(22.5 \mathrm{~g})$ which was extracted

\footnotetext{
*Author adress: Miroslav Novaković, Institute of Chemistry, Technology and Metallurgy, National Institute, University of Belgrade, Njegoseva 12, 11000 Belgarde, Serbia

E-mail: mironov@chem.bg.ac.rs

The manuscript received: November, 01, 2019.

Paper accepted: November, 28, 2019.
} 
twice with n-hexane (250 mL). The obtained extract (18 g) was subjected to dry-column flash chromatography on silica gel using n-hexane/ethyl acetate of different proportions. The elution progress was followed by TLC and ${ }^{1} \mathrm{H}$ NMR. The fraction that contained triterpenes was elueted with $80 \%$ EtOAc. This fraction was subjected to isocratic column chromatography on silica gel using n-hexane and isopropanol $(9 / 1, V / V)$ as eluent, to obtain 4 subfractions. Subfraction 2 (52.1 $\mathrm{mg}$ ) was further purified by preparative NP-HPLC (program 1) to obtain compounds 1 (1.5 $\mathrm{mg})$ and 2 (2.2 $\mathrm{mg})$.

The root of $E$. nicaeensis was first grounded and extracted with $96 \%$ ethanol. The obtained extract $(25 \mathrm{~g})$ was subjected to dry-column flash chromatography on silica gel using n-hexane and acetone in different proportion as eluent. The selected fraction $(2.1 \mathrm{~g})$, which was eluted with $15 \%$ acetone, was subjected to another dry-column flash chromatography on silica gel using n-hexane and acetone of different proportion (2/98 to 50/50) to obtain 4 subfractions. Subfraction $2(800 \mathrm{mg})$ was further purified by dry-column flash chromatography on silica gel using isocratic program with $8 \%$ acetone in $n$-hexane. The final purification was done using preparative NP-HPLC (Program 2) yielding compound 3 (2.8 $\mathrm{mg})$.

\section{Results and discussion}

Compounds 1 and 2 were isolated from the latex of E. nicaeensis. Their ${ }^{1} \mathrm{H}$ and ${ }^{13} \mathrm{C}$ NMR spectra (Figures 2-5) were very mutually similar and revealed the pattern of tetracyclic triterpene skeleton of tirucallane type with the hydroxyl groups at positions C-3, C-24, and C-25, as well as $\Delta^{7,8}$ double bond (Figure 1). The differences in the NMR data of 1 and 2 were noted for the chemical shifts of $\mathrm{H}-23$ and $\mathrm{H}-24$, as well as $\mathrm{C}-23$ and $\mathrm{C}-24$ (Table 1). For both compounds the position of $3-\mathrm{OH}$ was confirmed by the HMBC correlations $\mathrm{H}-3 / \mathrm{C}-1, \mathrm{C}-2, \mathrm{C}-4$ and $28-\mathrm{CH}_{3}, 29-$ $\mathrm{CH}_{3} / \mathrm{C}-3$. The 24-OH group was determined according to the $\mathrm{HMBC}$ correlations $\mathrm{H}-22, \mathrm{H}-23 / \mathrm{C}-24$ and the $25-\mathrm{OH}$ group according to the HMBC correlations $26-\mathrm{CH}_{3}, 27-$ $\mathrm{CH}_{3} / \mathrm{C}-25$. The position of the $\Delta^{7,8}$ double bond was deduced from the HMBC correlations H-5/C-7, H-9/C-7. Using the comparison with literature NMR data compound 1 was determined as (3S,24S)-tirucall-7-ene-3,24,25-triol known from Ailanthus excelsa [3], while compound 2 was its 24R diastereoisomer known from Celastrus stylosus [4]. HRESIMS confirmed molecular formula $\mathrm{C}_{30} \mathrm{H}_{52} \mathrm{O}_{3}$ for both structures - for compound 1 molecular ion $[\mathrm{M}+\mathrm{H}]^{+}$ was at $\mathrm{m} / \mathrm{z} 461.3980$ while for compound 2 it was at $\mathrm{m} / \mathrm{z}$ 461.3972 (theoretical value for $\mathrm{C}_{30} \mathrm{H}_{52} \mathrm{O}_{3}+\mathrm{H}$ is 461.3989).

Compound 3 was isolated from the root of $E$. nicaeensis. It belongs to the lanostane type of triterpenes, possessing 3-OH, $\Delta^{8,9}, \Delta^{23,24}$ double bonds and hydroperoxyl group at $\mathrm{C}-25$ (Figure 1). In the ${ }^{13} \mathrm{C}$ NMR spectrum characteristic chemical shifts of the double bonds were found at 131-134 ppm (four carbons) and oxygenated carbons at 79.2 and $82.5 \mathrm{ppm}$ (Figure 7). The position of 3-OH was confirmed by the HMBC correlations $\mathrm{H}-3 / \mathrm{C}-1, \mathrm{C}-2, \mathrm{C}-4$ and
28- $\mathrm{CH}_{3}, 29-\mathrm{CH}_{3} / \mathrm{C}-3$. The 24-OH group was determined according to the HMBC correlations $\mathrm{H}-22, \mathrm{H}-23 / \mathrm{C}-24$ and the 25-OH group according to the $\mathrm{HMBC}$ correlations $26-\mathrm{CH}_{3}, 27-\mathrm{CH}_{3} / \mathrm{C}-25$. The position of the $\Delta^{8,9}$ double bond was confirmed by the HMBC correlations $\mathrm{H}-7, \mathrm{H}-11 / \mathrm{C}-9$, $\mathrm{H}-6 / \mathrm{C}-8$, while the position of the $\Delta^{23,24}$ double bond was confirmed by the HMBC correlations $\mathrm{H}-22 / \mathrm{C}-23, \mathrm{C}-24$ and $\mathrm{H}-20 / \mathrm{C}-23$. Chemical shifts of the oxygenated carbons in the ${ }^{13} \mathrm{C}$ NMR spectrum of 3 at 79.2 and $82.5 \mathrm{ppm}$ were in accordance with the literature data for C-3 (and hydroxyl group in this position) and C-25 (hydroperoxyl group at C-25), respectively (Table 1 ). All the other chemical shifts were also in accordance with the literature data for inoterpene $\mathrm{C}$ isolated from Inonotus obliquus [5]. Chemical shift for $\mathrm{C}-25$ alcohol [6] differs for $11.7 \mathrm{ppm}$ in comparison with our experimental C-25 value and this was the reason why peroxyl group was proposed and later confirmed by the literature data. All NMR data are in agreement with inoterpene C (C-25 peroxyl derivative) [5].
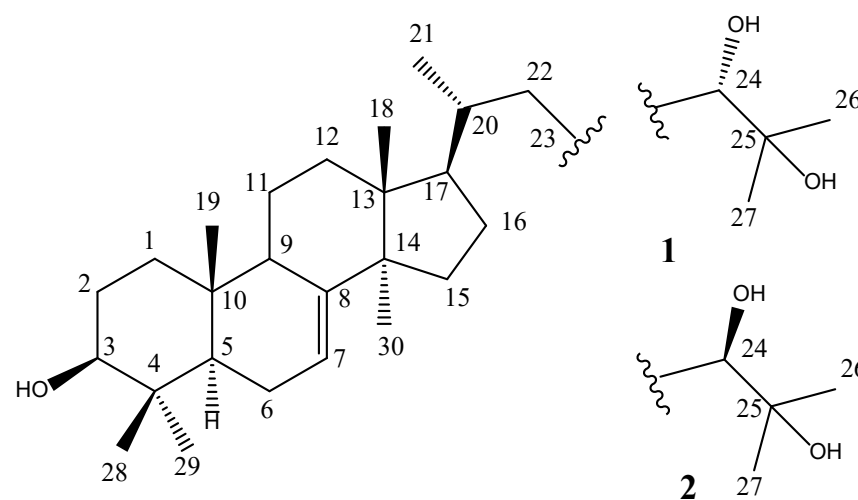

1

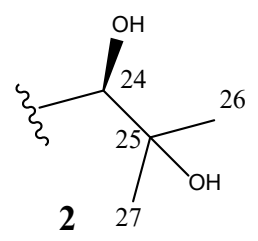

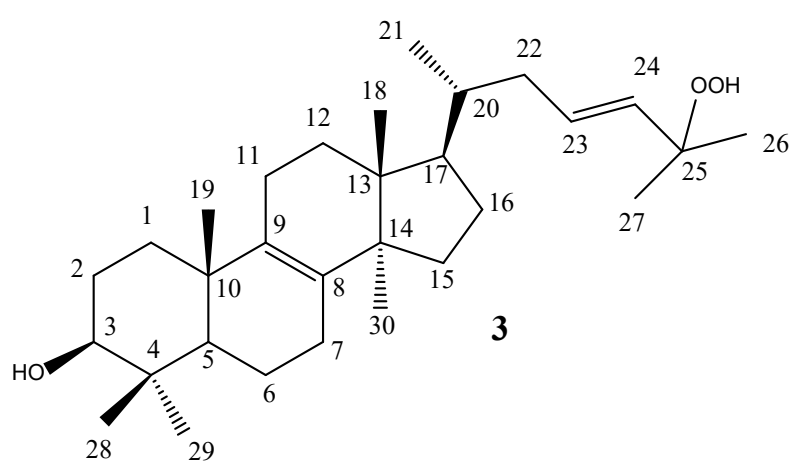

Figure 1. Tetracyclic triterpenes from E. nicaeensis 
Table 1. ${ }^{1} \mathrm{H}(500 \mathrm{MHz})$ and ${ }^{13} \mathrm{C}(125 \mathrm{MHz}) \mathrm{NMR}$ data for compounds 1 and $2\left(\mathrm{C}_{6} \mathrm{D}_{6}\right), 3\left(\mathrm{CDCl}_{3}\right)$ (ठ (ppm), J (Hz))

\begin{tabular}{|c|c|c|c|c|c|c|}
\hline & 1 & & 2 & & 3 & \\
\hline & $\delta_{\mathrm{H}}$ & $\delta_{\mathrm{C}}$ & $\delta_{\mathrm{H}}$ & $\delta_{\mathrm{C}}$ & $\delta_{\mathrm{H}}$ & $\delta_{\mathrm{C}}$ \\
\hline $1 \alpha$ & $0.96 \mathrm{~m}$ & & $0.95 \mathrm{~m}$ & & $1.77 \mathrm{~m}$ & \\
\hline $1 \beta$ & $1.53 \mathrm{~m}$ & & $1.52 \mathrm{~m}$ & & $1.21 \mathrm{~m}$ & \\
\hline $2 \alpha$ & & & $1.48 \mathrm{~m}$ & & $1.61 \mathrm{~m}$ & \\
\hline $2 \beta$ & & & $0.96 \mathrm{~m}$ & & $1.68 \mathrm{~m}$ & \\
\hline $3 \alpha$ & $3.03 \mathrm{dd}(11 ; 5)$ & 78.8 & $3.03 \mathrm{dd}(11 ; 5)$ & 78.8 & $3.24 \mathrm{dd}(12 ; 5)$ & 79.2 \\
\hline 4 & - & 39.1 & - & 39.1 & - & 39.2 \\
\hline 5 & $1.27 \mathrm{~m}$ & 51.1 & $1.26 \mathrm{~m}$ & 51.0 & $1.12 \mathrm{~m}$ & 51.2 \\
\hline $6 \alpha$ & $2.12 \mathrm{~m}$ & & $2.09 \mathrm{~m}$ & & $1.42 \mathrm{~m}$ & \\
\hline $6 \beta$ & $1.90 \mathrm{~m}$ & & $1.93 \mathrm{~m}$ & & $1.69 \mathrm{~m}$ & \\
\hline $7 \alpha$ & $5.35 \mathrm{dd}(7 ; 3)$ & & $5.34 \mathrm{dd}(7 ; 3)$ & & $2.07 \mathrm{~m}$ & \\
\hline $7 \beta$ & - & & - & & $1.97 \mathrm{~m}$ & \\
\hline 8 & - & 145.9 & - & 145.8 & - & 133.7 \\
\hline 9 & $2.25 \mathrm{~m}$ & 49.4 & $2.24 \mathrm{~m}$ & 49.3 & - & 134.6 \\
\hline 10 & - & 35.2 & - & 35.2 & - & 37.5 \\
\hline $11 \alpha$ & & & & & $1.59 \mathrm{~m}$ & \\
\hline $11 \beta$ & & & & & $1.37 \mathrm{~m}$ & \\
\hline $12 \alpha$ & $1.51 \mathrm{~m}$ & & $1.52 \mathrm{~m}$ & & $1.33 \mathrm{~m}$ & \\
\hline $12 \beta$ & $1.67 \mathrm{~m}$ & & $1.66 \mathrm{~m}$ & & $1.55 \mathrm{~m}$ & \\
\hline 13 & - & 43.9 & - & 44.0 & - & 44.4 \\
\hline 14 & - & 51.6 & - & 51.6 & - & 50.2 \\
\hline $15 \alpha$ & $1.88 \mathrm{~m}$ & & $1.88 \mathrm{~m}$ & & $1.68 \mathrm{~m}$ & \\
\hline $15 \beta$ & $1.80 \mathrm{~m}$ & & $1.83 \mathrm{~m}$ & & $1.78 \mathrm{~m}$ & \\
\hline $16 \alpha$ & $2.00 \mathrm{~m}$ & & $1.98 \mathrm{~m}$ & & $1.21 \mathrm{~m}$ & \\
\hline $16 \beta$ & $1.32 \mathrm{~m}$ & & $1.33 \mathrm{~m}$ & & $1.53 \mathrm{~m}$ & \\
\hline 17 & $1.55 \mathrm{~m}$ & 53.9 & $1.56 \mathrm{~m}$ & 53.7 & $1.53 \mathrm{~m}$ & 49.8 \\
\hline 18 & $0.99 \mathrm{~s}$ & 22.4 & $0,98 \mathrm{~s}$ & 22.4 & $0.80 \mathrm{~s}$ & 16.0 \\
\hline 19 & $0.78 \mathrm{~s}$ & 13.3 & $0.77 \mathrm{~s}$ & 13.3 & $0.96 \mathrm{~s}$ & 20.4 \\
\hline 20 & $1.48 \mathrm{~m}$ & 35.8 & $1,44 \mathrm{~m}$ & 37.0 & $1.55 \mathrm{~m}$ & 36.3 \\
\hline 21 & $0.90 \mathrm{~d}(6.5)$ & 18.7 & $0.92 \mathrm{~d}(6.5)$ & 19.1 & $0.83 \mathrm{~d}(6)$ & 19.4 \\
\hline $22 \alpha$ & $1.82 \mathrm{~m}$ & & $2.13 \mathrm{~m}$ & & 1.84 & \\
\hline $22 \beta$ & $1.23 \mathrm{~m}$ & & $0.98 \mathrm{~m}$ & & 2.41 & \\
\hline $23 \alpha$ & $1.43 \mathrm{~m}$ & & $1.57 \mathrm{~m}$ & & & \\
\hline $23 \beta$ & $1.37 \mathrm{~m}$ & & $1.15 \mathrm{~m}$ & & & \\
\hline 24 & $3.28 \mathrm{dd}(10 ; 2)$ & 78.2 & $3.18 \mathrm{dd}(10 ; 2)$ & 79.5 & $5.51 \mathrm{~d}(16)$ & 134.3 \\
\hline 25 & - & 72.7 & - & 72.8 & - & 82.5 \\
\hline 26 & $1.04 \mathrm{~s}$ & 23.4 & $1.04 \mathrm{~s}$ & 23.4 & $1.34 \mathrm{~s}$ & 24.6 \\
\hline 27 & $1.04 \mathrm{~s}$ & 26.6 & $1.04 \mathrm{~s}$ & 26.6 & $1.34 \mathrm{~s}$ & 24.7 \\
\hline 28 & $0.89 \mathrm{~s}$ & 15.0 & $0.88 \mathrm{~s}$ & 15.0 & $1.00 \mathrm{~s}$ & 28.3 \\
\hline 29 & $0.95 \mathrm{~s}$ & 27.8 & $0.96 \mathrm{~s}$ & 27.8 & $0.80 \mathrm{~s}$ & 15.7 \\
\hline 30 & $1.06 \mathrm{~s}$ & 27.5 & $1.06 \mathrm{~s}$ & 27.5 & $0.88 \mathrm{~s}$ & 24.6 \\
\hline
\end{tabular}




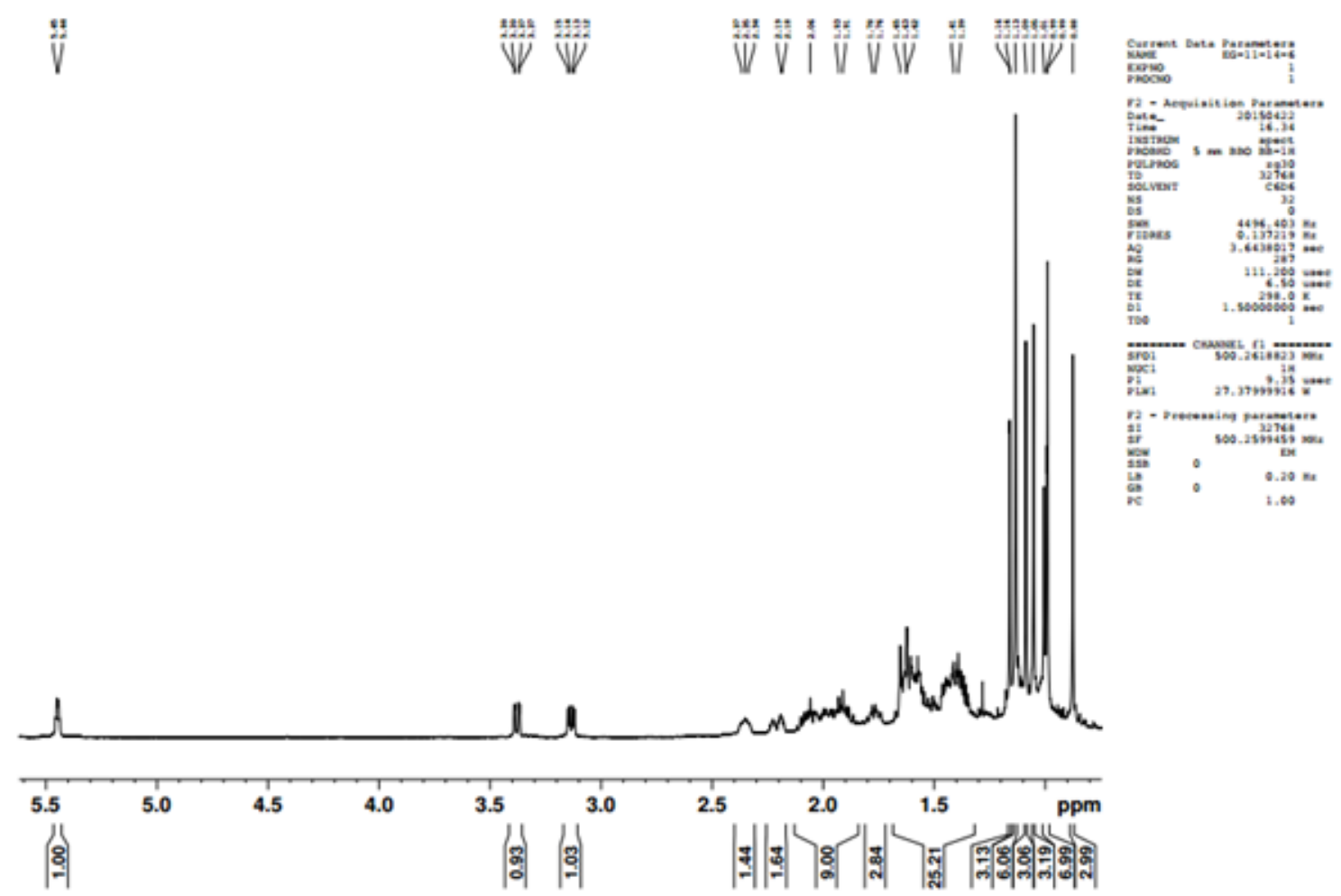

Figure 2. ${ }^{1} \mathrm{H}$ NMR spectrum of compound 1
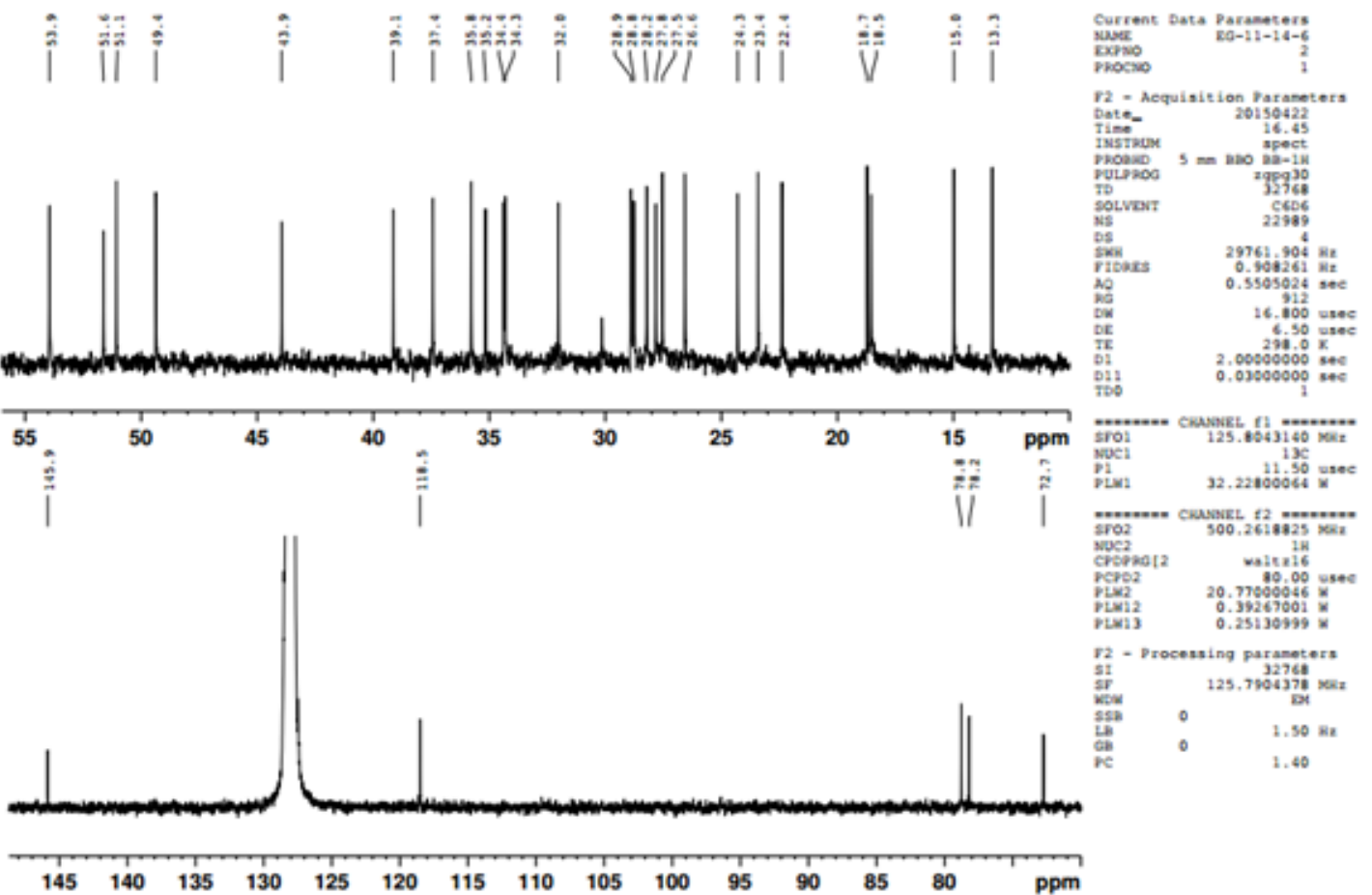

Figure $3 .{ }^{13} \mathrm{C}$ NMR spectrum of compound 1 


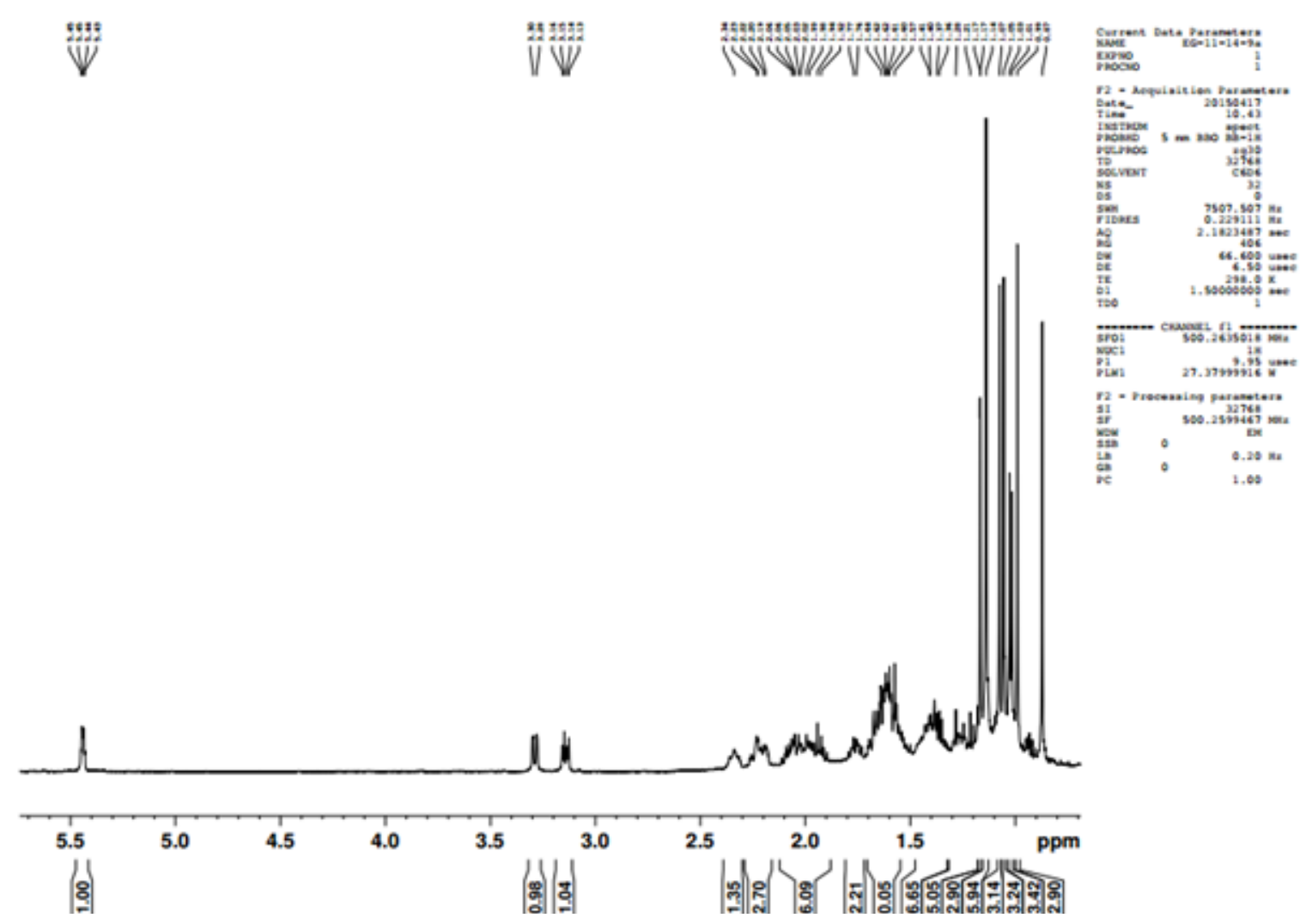

Figure 4. ${ }^{1} \mathrm{H}$ NMR spectrum of compound 2

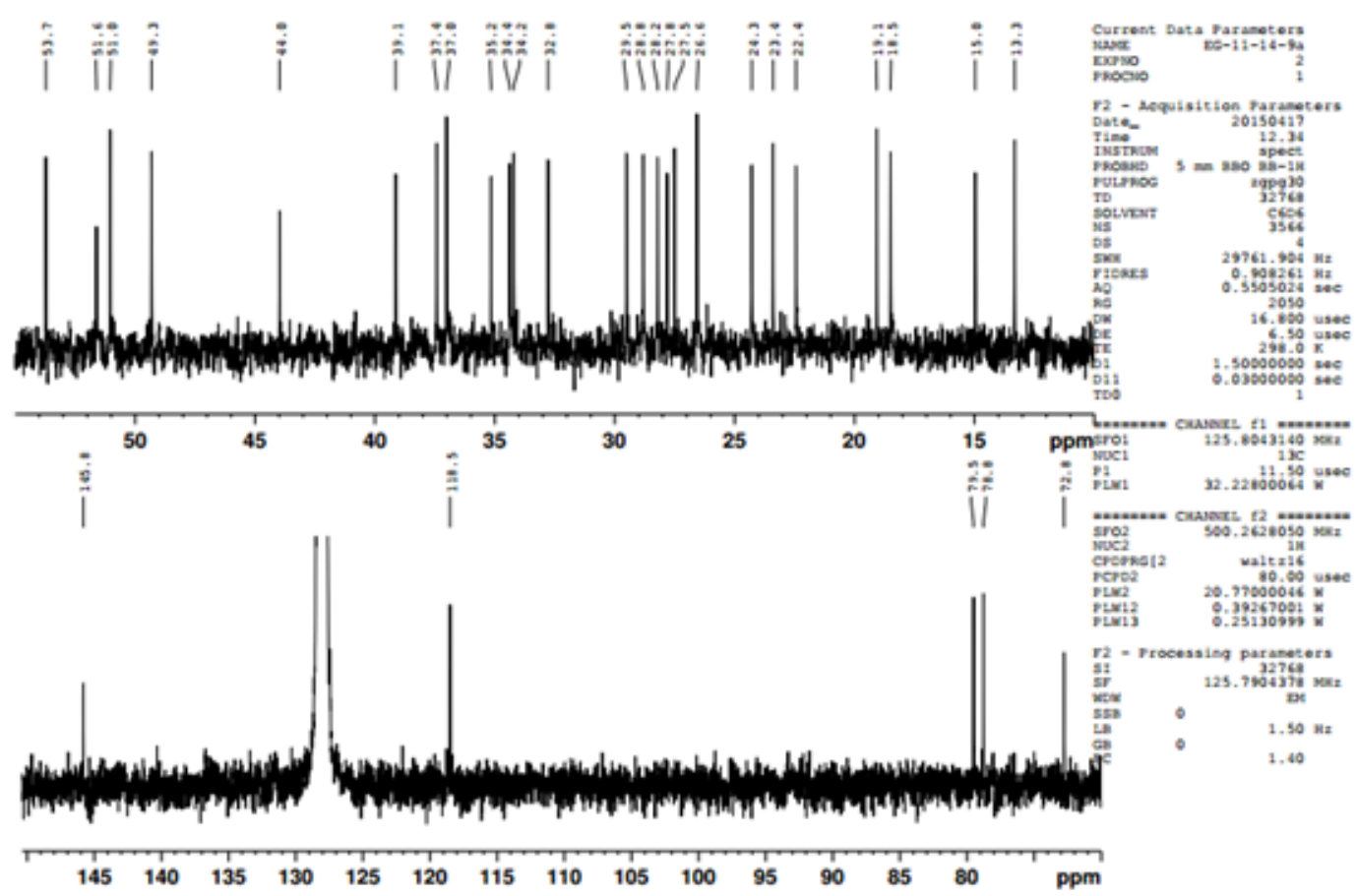

Figure $5 .{ }^{13} \mathrm{C}$ NMR spectrum of compound 2 


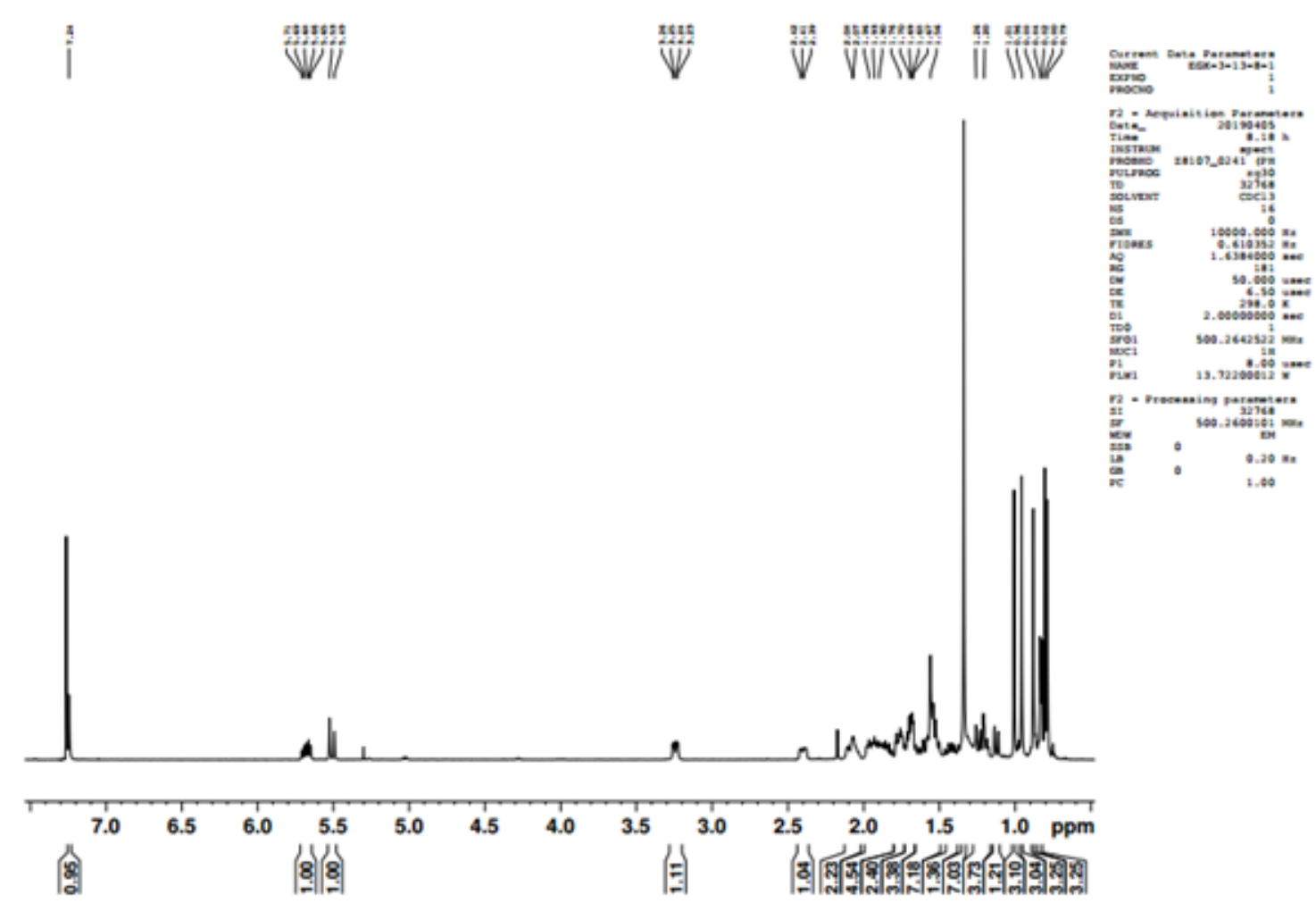

Figure 6. ${ }^{1} \mathrm{H}$ NMR spectrum of compound 3

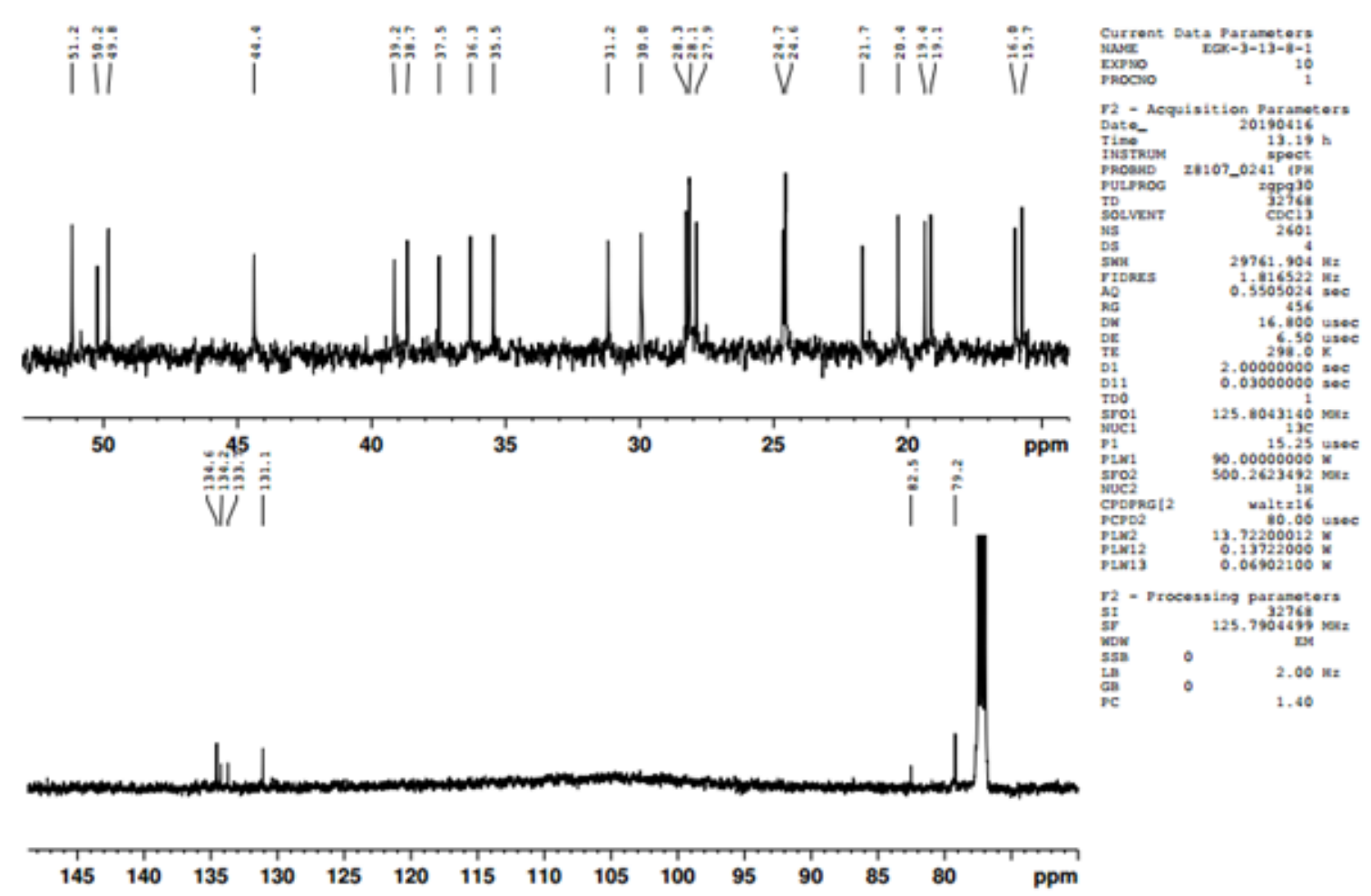

Figure $7 .{ }^{13} \mathrm{C}$ NMR spectrum of compound 3 


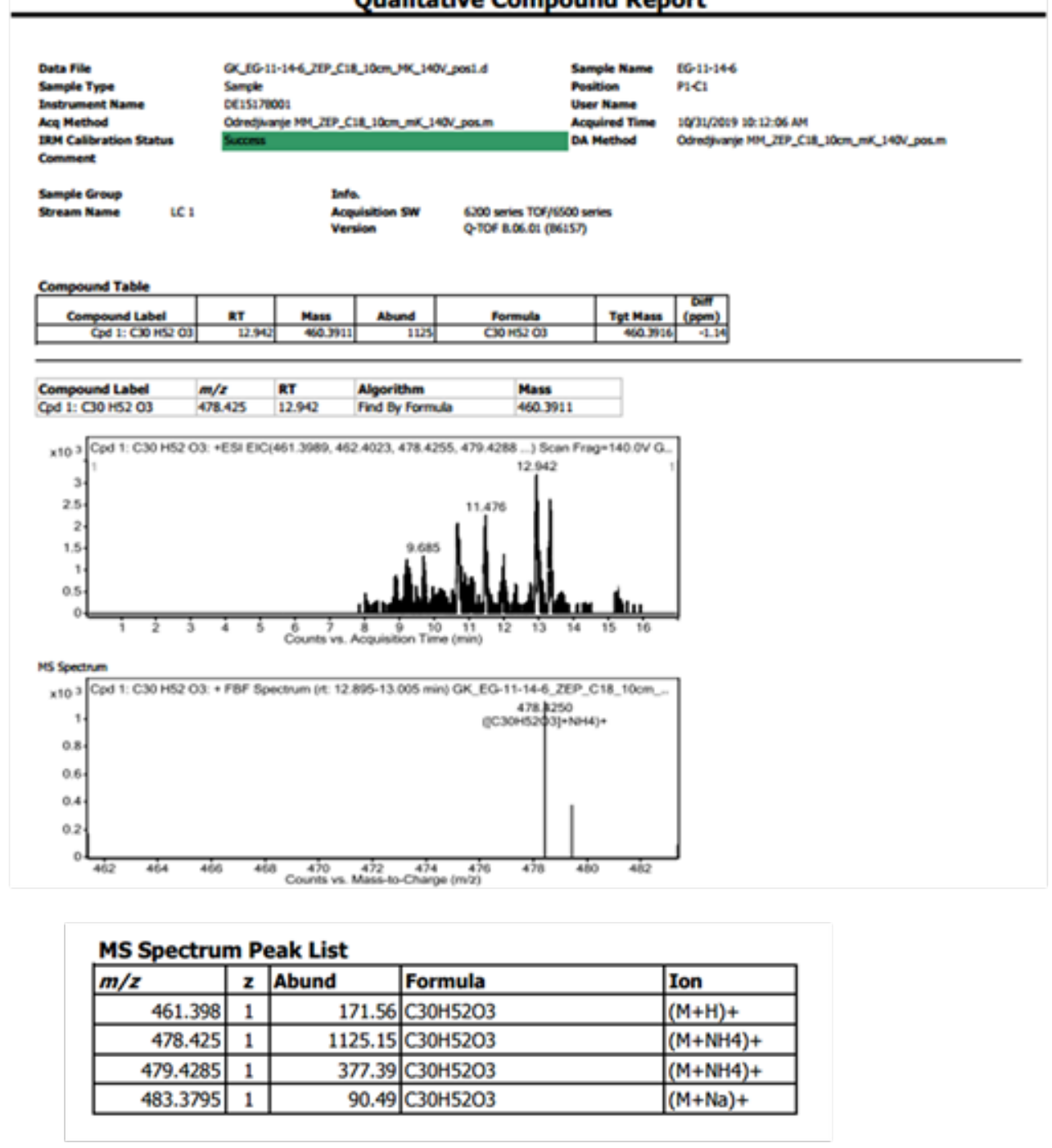

Figure 8. HRESIMS spectrum of compound 1 


\section{Qualitative Compound Report}

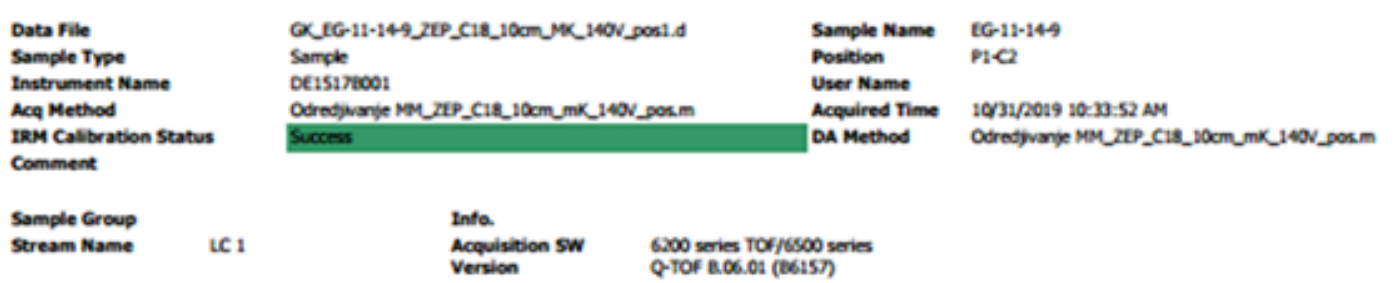

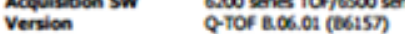

\begin{tabular}{|c|c|c|c|c|c|c|}
\hline & & & & & & \\
\hline Compound Label & RT & Mass & Abund & Formuls & Tot Mass & $(\mathrm{ppm})$ \\
\hline Cod 1: COOHSO 03 & 13.019 & 460.3907 & 738 & $\mathrm{COON6203}$ & 4603516 & -2.00 \\
\hline
\end{tabular}
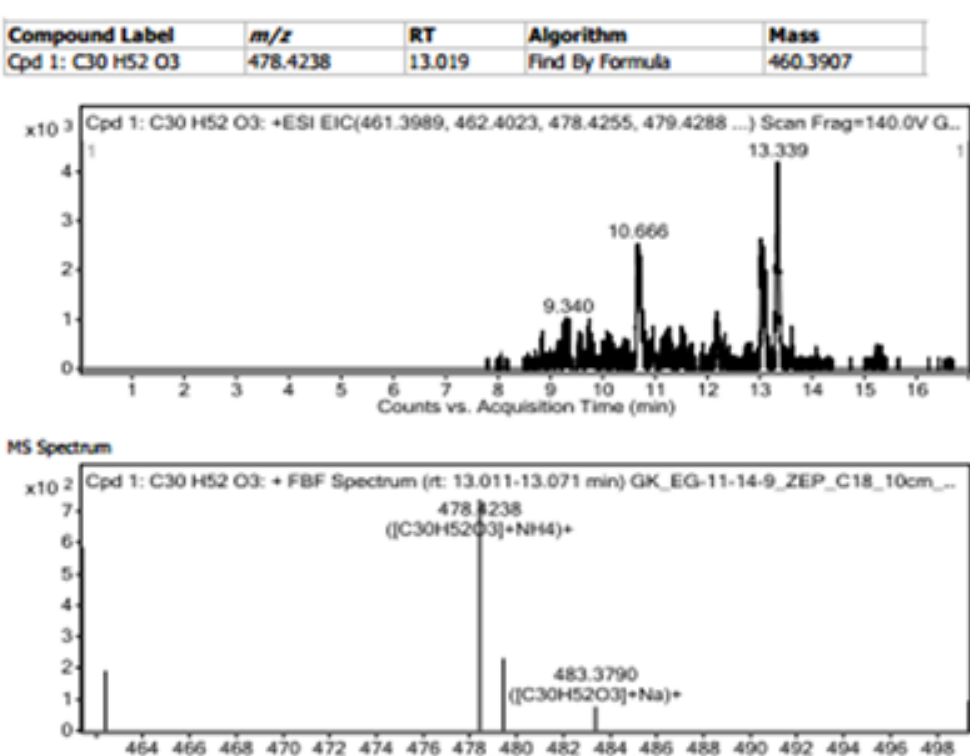

MS Spectrum Peak List
\begin{tabular}{|r|r|r|l|l|}
\hline $\boldsymbol{m} / \boldsymbol{z}$ & $\boldsymbol{z}$ & \multicolumn{1}{|l|}{ Abund } & Formula & Ion \\
\hline 461.3972 & 1 & 586.25 & $\mathrm{C} 30 \mathrm{H} 52 \mathrm{O}$ & $(\mathrm{M}+\mathrm{H})+$ \\
\hline 462.3999 & 1 & 192.19 & $\mathrm{C} 3 \mathrm{OH} 52 \mathrm{O}$ & $(\mathrm{M}+\mathrm{H})+$ \\
\hline 478.4238 & 1 & 738.31 & $\mathrm{C} 3 \mathrm{OH} 52 \mathrm{O}$ & $(\mathrm{M}+\mathrm{NH} 4)+$ \\
\hline 479.4276 & 1 & 231.79 & $\mathrm{C} 30 \mathrm{H} 52 \mathrm{O}$ & $(\mathrm{M}+\mathrm{NH} 4)+$ \\
\hline 483.379 & 1 & 77.45 & $\mathrm{C} 30 \mathrm{H} 52 \mathrm{O}$ & $(\mathrm{M}+\mathrm{Na})+$ \\
\hline 499.3681 & 1 & 96.4 & $\mathrm{C} 30 \mathrm{H} 52 \mathrm{O}$ & $(\mathrm{M}+\mathrm{K})+$ \\
\hline
\end{tabular}

Figure 9. HRESIMS spectrum of compound 2

\section{Conclusion}

This manuscript describes isolation and structure elucidation of three triterpenoid compounds from milkweed Euphorbia nicaeensis. Even though these compounds had been isolated before, this was the first time that they were isolated from this plant species. Their structure elucidation was done using NMR analysis revealing (3S, 24S)-tirucall-7-ene-3,24,25-triol, (3S, 24R)-tirucall7-ene-3,24,25-triol and inoterpene $C$ as their structures.
Their biological activity should be further analyzed for the purpose of testing their anti-inflammatory activity since similar compounds have already shown such activity. Another reason for further analysis should be the antimicrobial activity against plant pathogens, especially for compounds 1 and 2, since they were isolated from the latex which represents the plant protection system. 


\section{Acknowledgements}

This study was supported by the Ministry of Education, Science and Technological Development of the Republic of Serbia Project no 172053

\section{References}

[1] Q. W. Shi, X. H. Su, H. Kiyota. Chemical and Pharmacological Research of the Plants in Genus Euphorbia. Chemical Reviewes, 108 (2008) 4295-4327.

[2] G. Krstić, M. Jadranin, N. M. Todorović, M. Pešić, T. Stanković, I. S. Aljančić, V. V. Tešević. Jatrophane diterpenoids with multidrug-resistance modulating activity from the latex of Euphorbia nicaeensis. Phytochemistry, 148 (2018) 104-112.
[3] M. M. Sherman, R. P. Borris, M. Ogura, G.A. Cordell, N. R. Farnsworth. 3S,24S,25-trihydroxytirucall-7-ene from Ailanthus excelsa. Phytochemistry, 19 (1980) 1499-1501.

[4] W. G. Shan, Z. L. Gao, Y. M. Ying, J. G. Xiang, F. S. Wang, Z. J. Zhan. Tirucallane-Type Triterpenoids from Celastrus stylosus Wall. Helvetica Chimica Acta, 97 (2014) 15261530.

[5] S. Nakamura, J. Iwami, H. Matsuda, S. Mizuno, M. Yoshikawa. Absolute stereostructures of inoterpenes A-F from sclerotia of Inonotus obliquus. Tetrahedron, 65(12) (2009) 2443-2450.

[6] Y. Leong, Harrison. (20R,23E)-Eupha-8,23-diene-3b,25diol from Tripetalum cymosum. Phytochemistry, 50(5) (1999) 849-857.

\section{TETRACIKLIČNI TRITERPENOIDI IZ VRSTE Euphorbia nicaeensis All.}

\section{Gordana B. Krstić1, Miroslav M. Novaković², Milka B. Jadranin², Vele V. Tešević1}

1Univerzitet u Beogradu, Hemijski fakultet, Beograd, Srbija

2Univerzitet u Beogradu, Institut za hemiju, tehnologiju i metalurgiju, Nacionalni institut, Beograd, Srbija

U ovom radu, tri tetraciklična triterpena: (3S,24S)-tirukal-7-en-3,24,25-triol (1), (3S, 24R)-tirukal-7-en-3,24,25-triol (2) i inoterpen C (3) su izolovana iz mlečike Euphorbia nicaeensis All. koristeći brzu hromatografiju na suvom stubu silika gela i semipreparativnu normalno-faznu HPLC. Strukture su određene na osnovu 1D i 2D NMR spektara i poređenjem sa literaturom. lako su ova tri jedinjenja ranije izolovana iz drugih biljnih vrsta, ovo je prvi put da su izolovana iz E. nicaeensis.
(ORIGINALNI NAUČNI RAD) UDK 582.682.1:547.596:543.544
Ključne reči: tetraciklični triterpeni, Euphorbia nicaeensis, lateks, brza hromatografija na suvom stubu, NP HPLC, NMR analiza 